\title{
RESPONS MAHASISWA TERHADAP BUKU PANDUAN DAN KEGIATAN PELATIHAN "TEKNIK MONITORING KURA-KURA Cyclemys oldhamii"
}

\section{(Students' response of the Guidebook and Training Activities "Monitoring Technique of the Cyclemys oldhamir" Tortoises)}

\author{
Annisa Puji Astuti ${ }^{1 *}$, Aceng Ruyani ${ }^{2}$, Wiryono ${ }^{2}$ \\ ${ }^{1}$ Mahasiswa Pascasarjana Pendidikan IPA, Universitas Bengkulu, 38371 \\ ${ }^{2}$ Dosen Pascasarjana Pendidikan IPA, Universitas Bengkulu, 38371 \\ *Email: annisapuijastuti@rocketmail.com
}

\begin{abstract}
This study aimed to know the students's response to the guidebooks and training activities entitled "Monitoring Technique of the Cyclemys oldhamii Tortoise " in the ex situ conservation area Taman Pintar University of Bengkulu. The results showed that students responded positively to the guidebooks and training activities. Forestry students was very interested in the field practices related to the technique and monitoring activities of the C.oldhamii tortoise, while MIPA students was interested in knowledge of the habitat, morphology, and its conservation. Forestry students showed the biggest response to conserve C.oldhamii and other tortoises, meanwhile MIPA students was more interested to do the next observations and research about C.oldhamii and other tortoises for thesis research. Forestry and MIPA students could explain the benefits and plans after the training activities "Technique Monitoring of the Cyclemys oldhamii Tortoise" well.
\end{abstract}

Key words: Response, Guidebook, Training activities, Cyclemys oldhamii

\begin{abstract}
ABSTRAK
Penelitian ini bertujuan untuk mengetahui respons mahasiswa terhadap buku panduan dan kegiatan pelatihan yang berjudul "Teknik Monitoring Kura-kura Garis Hitam (Cyclemys oldhamii)" di area konservasi ex situ Taman Pintar Universitas Bengkulu. Hasil penelitian menunjukkan bahwa mahasiswa memberikan respons positif terhadap buku panduan dan kegiatan pelatihan. Mahasiswa jurusan Kehutanan memiliki ketertarikan yang tinggi terhadap kegiatan praktik lapangan terkait teknik dan kegiatan monitoring kura-kura C.oldhamii, sedangkan mahasiswa jurusan MIPA tertarik dengan pengetahuan mengenai habitat, morfologi, dan konservasinya. Mahasiswa jurusan Kehutanan memberikan respons yang besar untuk ikut mengkonservasi kura-kura C.oldhamii maupun kura-kura lainnya, sedangkan mahasiswa jurusan MIPA lebih tertarik untuk melakukan observasi dan penelitian selanjutnya mengenai kura-kura C.oldhamii maupun kura-kura lainnya untuk penelitian tugas akhir. Mahasiswa jurusan kehutanan dan MIPA Biologi dapat menjelaskan dengan baik mengenai manfaat dan rencana atau tindak lanjut yang akan dilakukan setelah mengikuti kegiatan pelatihan "Teknik Monitoring Kura-kura Cyclemys oldhamii".
\end{abstract}

Kata kunci: Respons, Buku Panduan, Kegiatan Pelatihan, Cyclemys oldhamii

\section{PENDAHULUAN}

Telah dikembangkan sebuah buku panduan praktik yang berjudul "Teknik Monitoring Kura-kura Cyclemys oldhamir"
(Astuti et al. 2017). Kura-kura C.oldhamii adalah kura-kura semi-aquatik yang dapat hidup dengan baik di darat dan perairan tawar. Kura-kura C.oldhamii merupakan 
anggota dari genus Cyclemys berplastron gelap (Fritz et al.2008) dengan ciri khas pada bagian plastron terdapat garis-garis hitam (Brakels et al.2016) sehingga seringkali disebut sebagai kura-kura garis hitam. Di Provinsi Bengkulu, C.oldhamii tersebar di Kabupaten Bengkulu Utara, Kepahiyang, Seluma, dan Mukomuko (Putri et al. 2011). Pemilihan kura-kura jenis ini karena berada pada kategori Appendix II (CITES 2016) dan NE atau Not Evaluated (IUCN 2013) karena belum dievaluasi akibat kurangnya informasi mengenai taksonomi dan keberadaan C.oldhamii, dan tergolong dalam jenis yang belum terancam punah namun jika perdagangan internasional tidak dikontrol maka terdapat kemungkinan terjadinya resiko kepunahan. Sementara itu Universitas Bengkulu khususnya Prodi Pascasarjana Pendidikan IPA telah mengembangkan sebuah danau buatan yang diberi nama area konservasi ex situ Taman Pintar dengan slogan "UNIB campus, a safe home for turtles". Di area ini terdapat sekitar 25 individu C.oldhamii yang telah diberi tagging (Sinaga et al 2016). Perlu dilakukan monitoring dan pengawasan terhadap kura-kura di area ini agar dapat bertahan hidup dengan baik meskipun di luar habitat aslinya.

Buku panduan praktik ini berisikan antara lain: Syarat Peserta Kegiatan Pelatihan, Pendahuluan, Mengidentifikasi Morfologi C.oldhamii, Menentukan Jenis Kelamin pada Kura-kura, Memperkirakan usia kura-kura, Menentukan Kode tagging pada kura-kura, Mengukur Pertumbuhan Kura-kura, Menggunakan Aplikasi Herp, Merangkai Turtle trap, Menggunakan Radio Telemetri, dan Menentukan area jelajah kura-kura. Kerangka buku panduan kegiatan pelatihan "Teknik Monitoring Kurakura C.oldhamii" dapat dilihat pada gambar berikut.

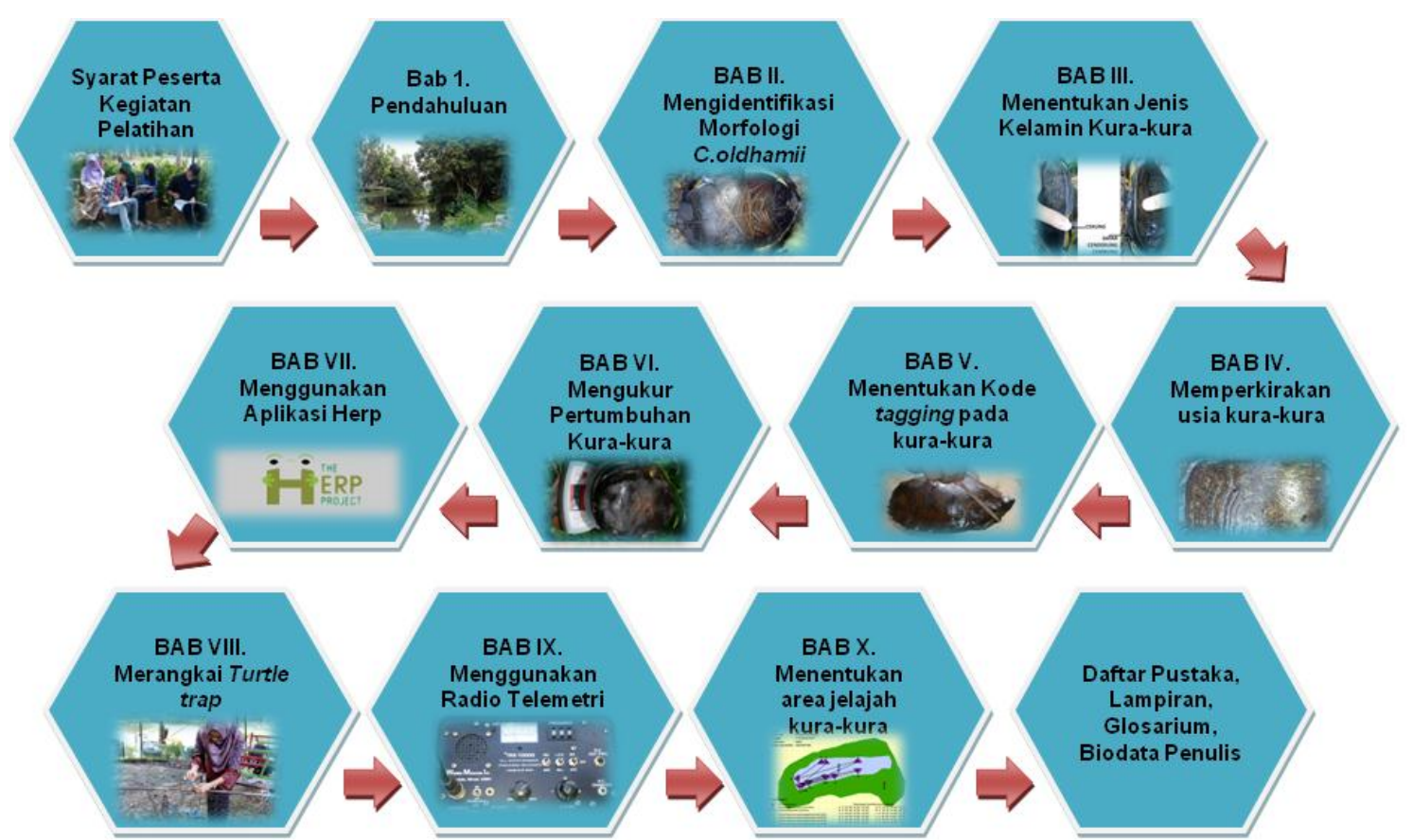

Gambar 1. Kerangka buku panduan kegiatan pelatihan "Teknik Monitoring Kura-kura $C$. oldhamir" (Astuti, et al)

Buku panduan dan kegiatan pelatihan "Teknik Monitoring Kura-kura Cyclemys oldhamir" ini diadakan dengan tujuan untuk memberikan keterampilan kepada mahasiswa terkait monitoring kura-kura khususnya pada C.oldhamii dan menginspirasi mereka untuk melakukan penelitian selanjutnya (tugas akhir atau skripsi). Selain itu kegiatan ini menekankan pentingnya suatu konservasi dilakukan terhadap hewan yang terancam keberadaannya, dan menyadarkan mahasiswa untuk lebih arif dalam memperhatikan lingkungan sekitar, dalam hal ini kura-kura C.oldhamii yang keberadaannya seringkali tidak dipedulikan.

Respons menurut KBBI dapat diartikan sebagai tanggapan atau reaksi atau 
jawaban. Sobur (2013) menyatakan bahwa respons mengandung pengertian suatu sikap atau tingkah laku terkait pengaruh atau penolakan, penggambaran rasa suka atau tidak suka terhadap sesuatu. Secara umum, respons dapat dipengaruhi oleh beberapa faktor (Mulyani 2007), antara lain: a) diri responden yang berusaha me memberikan interpretasi terhadap sesuatu yang dilihatnya dan dipengaruhi oleh sikap, motif, kepentingan, dan harapan, b) sifatsifat responden yang berupa gerakan, suara, ukuran, tindakan, dan ciri lain yang dapat menentukan cara pandang responden, c) faktor situasi yang ikut berperan dalam pembentukan dan tanggapan responden. Dalam penelitian ini, respons diartikan sebagai tanggapan dan reaksi mahasiswa terhadap buku panduan dan kegiatan pelatihan mengenai "Teknik Monitoring Kura-kura Cyclemys oldhamir'. Setelah kegiatan pelatihan ini dilakukan maka mahasiswa akan mengisi angket respons yang berisi 15 butir pernyataan terkait buku panduan dan kegiatan pelatihan. Selain itu terdapat 2 butir pertanyaan untuk mengetahui tanggapan mahasiswa terkait manfaat yang didapatkan dan tindak lanjut yang akan dilakukan setelah kegiatan pelatihan ini berlangsung.

\section{METODE}

\section{Waktu dan lokasi penelitian}

Pengembangan buku

panduan

dilakukan pada bulan Maret sampai Mei 2017, dan kegiatan pelatihan dilaksanakan pada tanggal 20-21 Mei 2017 di Learning Centre dan area konservasi ex situ Taman Pintar Universitas Bengkulu.

\section{Pengumpulan data}

Pengumpulan data melalui observasi berperanserta (participant observation) karena peneliti terlibat langsung dalam kegiatan pelatihan "Teknik Monitoring Kurakura Cyclemys oldhamil' (Sugiyono 2010), kuesioner menggunakan angket respons mahasiswa terhadap buku panduan dan kegiatan pelatihan, dokumentasi (foto dan rekaman), dan kajian pustaka. Pemilihan responden (mahasiswa) dilakukan dengan menyebarkan poster terkait kegiatan pelatihan dengan beberapa syarat antara lain a) berada pada minimal semester 4 dan maksimal semester 6 , b) berasal dari jurusan kehutanan/ MIPA Biologi/ FKIP Biologi/ FKIP PGSD, dan c) telah menempuh mata kuliah minimal Biologi Dasar/ Ilmu Lingkungan/ Zoologi Vertebrata.

\section{Analisis data}

Analisis data dilakukan secara deskriptif dengan mengelompokkan jawaban dari angket respons mahasiswa kedalam kategori sangat negatif, negatif, positif, dan sangat positif. Selain itu juga dilakukan pengelompokan respons mahasiswa terkait pertanyaan pendukung mengenai manfaat dan tindak lanjut yang akan dilakukan setelah mengikuti kegiatan pelatihan ini menjadi 2 kelompok berdasarkan asal jurusan dan dihitung persentasenya, kemudian dikelompokkan menjadi beberapa kriteria respons yaitu tidak baik, kurang baik, cukup, baik, dan sangat baik.

\section{HASIL DAN PEMBAHASAN}

Penelitian mengenai respons mahasiswa terhadap buku panduan dan kegiatan pelatihan "Teknik Monitoring Kurakura C.oldhamii" dilakukan dengan memberikan angket respons yang berisi 15 butir pernyataan dan 2 butir pertanyaan pendukung kepada 12 orang mahasiswa setelah kegiatan pelatihan dilaksanakan. Setiap pernyataan angket memiliki 4 kriteria pilihan jawaban yaitu STS (Sangat Tidak Setuju), TS (Tidak Setuju), S (Setuju), dan SS (Sangat Setuju).

Tabel 1. Kriteria respons mahasiswa terhadap buku panduan dan kegiatan pelatihan "Teknik Monitoring Kura-kura C.oldhamil"

\begin{tabular}{|ccc|}
\hline No & Interval skor & Kriteria respons \\
\hline $\mathbf{1}$ & $15,00-26,00$ & Sangat negatif \\
\hline $\mathbf{2}$ & $26,01-37,00$ & Negatif \\
\hline $\mathbf{3}$ & $37,01-48,00$ & Positif \\
\hline $\mathbf{4}$ & $48,01-59,00$ & Sangat positif \\
\hline
\end{tabular}


Perhitungan terhadap jawaban angket tersebut didapatkan rata-rata skor respons keseluruhan mahasiswa sebesar 47,41. Berdasarkan Tabel 1, rata-rata skor ini tergolong ke dalam kriteria positif. Maka dapat disimpulkan bahwa secara keseluruhan, mahasiswa memberikan respons yang positif terhadap buku panduan dan kegiatan pelatihan "Teknik Monitoring Kura-kura C.oldhamil'.

Pada angket tersebut terdapat 2 buah pertanyaan pendukung berbentuk uraian yang mengarahkan responden untuk memberikan jawaban sesuai dengan argumentasinya masing-masing. Pertanyaan pertama yaitu : Apa manfaat yang saudara/i dapatkan setelah mengikuti kegiatan "Teknik Monitoring Kura-kura C.oldhamir'? Pada pertanyaan ini jawaban dan respons mahasiswa beragam, namun dapat dikelompokkan menjadi 3 aspek jawaban yaitu: a) dapat mengetahui berbagai teknik dalam kegiatan monitoring kura-kura garis hitam (C.oldhamii) (kode A), b) dapat menambah pengetahuan tentang habitat, morfologi, dan konservasi kura-kura garis hitam (C.oldhamii) (kode B), c) dapat menambah pengalaman (kode $\mathrm{C}$ ), dan d) dapat menjaga kelestarian kura-kura (kode D).

Pertanyaan kedua yaitu: Rencana atau tindak lanjut apa yang akan saudara/i lakukan setelah mengikuti kegiatan "Teknik Monitoring Kura-kura C.oldhamii"? Respons dan jawaban atas pertanyaan ini beragam dan dapat dikelompokkan menjadi 4 aspek jawaban yaitu a) mempelajari tentang kurakura garis hitam, sehingga dapat melakukan penelitian skripsi (tugas akhir) dengan tema observasi kura-kura garis hitam (C.oldhamii) maupun kura-kura lainnya (kode E), b) jika menemukan kura-kura akan memberitahukannya kepada pihak yang lebih mengerti, misalnya Learning Center Universitas Bengkulu (kode F), c) menghimbau teman-teman, saudara, dan orang-orang terdekat untuk ikut serta dalam kegiatan pelestarian kura-kura garis hitam (C.oldhamii) maupun kura-kura lainnya (kode G), dan d) membuat komunitas atau grup belajar dengan tema kura-kura (kode H)

Respons mahasiswa untuk pertanyaan pendukung dapat diuraikan berdasarkan asal jurusan disajikan dalam Gambar 2:

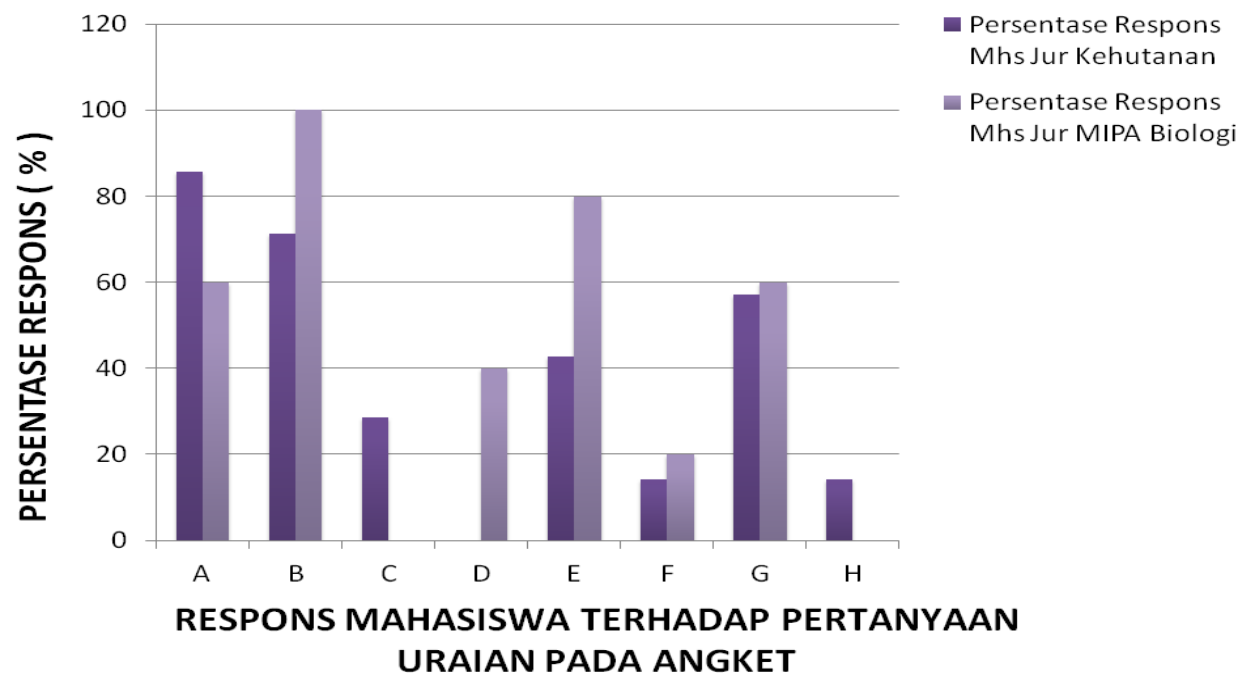

Gambar 2. Grafik persentase respons mahasiswa terhadap pertanyaan uraian pada angket

Gambar 2 menunjukkan bahwa pada pertanyaan no 1 terkait manfaat yang didapatkan dalam mengikuti kegiatan pelatihan yang dilakukan yaitu sebesar $\mathbf{8 5 , 7 \%}$ mahasiswa jurusan Kehutanan merespons dapat mengetahui berbagai teknik dalam kegiatan monitoring kurakura garis hitam (C.oldhamii), sedangkan
$100 \%$ mahasiswa MIPA Biologi merespons dapat menambah pengetahuan tentang habitat, morfologi, dan konservasi kura-kura garis hitam (C.oldhamii). Hal ini menunjukkan bahwa secara keseluruhan, mahasiswa jurusan Kehutanan memiliki ketertarikan yang tinggi terhadap kegiatan praktik lapangan 
terkait teknik dan kegiatan monitoring, sedangkan mahasiswa jurusan MIPA secara keseluruhan memiliki minat terkait pengetahuan mengenai habitat, morfologi, dan konservasinya. Pertanyaan no 2 terkait rencana dan tindak lanjut yang akan dilakukan setelah mengikuti kegiatan pelatihan didapatkan persentase sebesar $\mathbf{5 7 , 1} \%$ mahasiswa jurusan Kehutanan merespons menghimbau teman-teman, saudara, dan orang-orang terdekat untuk ikut serta dalam kegiatan pelestarian kurakura garis hitam (C.oldhamii) maupun kura-kura lainnya, sedangkan $\mathbf{8 0} \%$ mahasiswa jurusan MIPA Biologi merespons akan mempelajari tentang kura-kura garis hitam, sehingga dapat melakukan penelitian skripsi (tugas akhir) dengan tema observasi kura-kura garis hitam (C.oldhamil) maupun kurakura lainnya. Hal ini menunjukkan bahwa mahasiswa jurusan MIPA Biologi lebih tertarik untuk melakukan observasi kurakura C.oldhamii maupun kura-kura lainnya dan melakukan penelitian lebih lanjut khususnya untuk penelitian tugas akhir dibandingkan mahasiswa dari jurusan Kehutanan, dan mahasiswa jurusan Kehutanan memiliki respons yang besar untuk ikut menjaga kelestarian kura-kura garis hitam (C.oldhamii) maupun kura-kura lainnya.

Berdasarkan pertanyaan pendukung tersebut dapat dihitung skornya dan didapatkan rata-rata skor sebesar 62,91 dan tergolong dalam kategori baik. Hal ini menunjukkan bahwa secara keseluruhan, mahasiswa jurusan kehutanan dan MIPA Biologi dapat menjelaskan mengenai manfaat dan rencana atau tindak lanjut yang akan dilakukan setelah mengikuti kegiatan "Teknik Monitoring Kura-kura Garis Hitam atau Cyclemys oldhamil" dengan baik

\section{KESIMPULAN}

Kesimpulan dalam penelitian ini adalah mahasiswa memberikan respons positif terhadap buku panduan dan kegiatan pelatihan. Mahasiswa dapat memberikan respons yang baik terkait manfaat dan tindak lanjut setelah kegiatan pelatihan "Teknik Monitoring Kura-kura Garis Hitam atau Cyclemys oldhamii" dilaksanakan.

\section{UCAPAN TERIMA KASIH}

Terima kasih kami sampaikan kepada semua pihak yang telah membantu terselesaikannya penelitian ini, orang tua, teman-teman, adik-adik mahasiswa jurusan Kehutanan dan MIPA Biologi, semua dosen dan staf Program Studi Pascasarjana Pendidikan IPA Universitas Bengkulu.

\section{DAFTAR PUSTAKA}

Astuti AP, Wiryono, Ruyani A. 2017. Pedoman Monitoring Kura-kura Semi Akuatik, Studi pada Kurakura Garis Hitam (Cyclemys oldhamii). Bengkulu (ID): Unit Penerbit FKIP Universitas Bengkulu.

Brakels P, Samban C, Jones C. 2016. Range extension of Cyclemys atripons Iverson \& McCord 1997 with the discovery of a population in Oddar Meanchey Province, Northwestern Cambodia (KH). Cambodian Journal of Natural History. 2016(1): 20-22

CITES. 2016. Appendices I, II and III valid from 10 March 2016.

Fritz U, Guicking D, Auer M, Sommer RS, Wink M, Hundsdörfer AK. 2008. Diversity of the southeast Asian leaf turtle genus Cyclemys: How many leaves on its tree of life?. J.Zoologica Scripta. 2008 (37): 367-390.

http://kbbi.web.id/respons

IUCN. 2013. Sixteenth Meeting of the Conference of the Parties, Consideration of Proposals for Amendments to Appendices I and II. Thailand (TH): Convention on International Trade in Endangered Species of Wild Fauna and Flora

Putri YA, Ruyani A, Muslim C. 2011. Studi Biodistribusi Kura-kura Air Tawar dan Terestrial di Kabupaten Mukomuko serta Implementasi Model Pembelajaran Kooperatif Tipe Think, Pair, Square (TPSQ) 
dengan Menggunakan LKS pada Siswa SMPN 14 Mukomuko, Bengkulu [Thesis]. Bengkulu (ID). Universitas Bengkulu

Sinaga M, Ruyani A, Primairyani A. 2016. Studi Adaptasi Kura-kura Garis Hitam (Cyclemys oldhamii) pada Kolam Taman Pintar FKIP Universitas Bengkulu sebagai Sumber Belajar Konservasi ex-situ bagi Siswa SMA [Undergraduated Thesis]. Bengkulu (ID). Universitas Bengkulu.

Mulyani, Sri. 2007. Pengantar

Psikologi Sosial,USU Press, Medan

Sobur A. 2003. Psikologi Umum.

Pusaka Setia. Bandung

Sugiyono. 2010. Metode Penelitian

Pendidikan: Pendekatan

Kuantitatif, Kualitatif, dan $R \& D$.

Bandung (ID): Alfabeta 